\title{
The Flooding of Ur in Mesopotamia in New Perspectives
}

\author{
Nils-Axel Mörner \\ Paleogeophysics \& Geodynamics, Stockholm, Sweden \\ Email: morner@pog.nu
}

Received 25 October 2014; revised 23 November 2014; accepted 25 December 2014

Academic Editor: Hugo G. Nami, National Council of Scientific and Technical Research (CONICET), Departamento de Ciencias Geológicas, University of Buenos Aires, Argentina

Copyright (C) 2015 by author and Scientific Research Publishing Inc.

This work is licensed under the Creative Commons Attribution International License (CC BY).

http://creativecommons.org/licenses/by/4.0/

(c) (i) Open Access

\begin{abstract}
At around 5000 years BP sea level peaked in the Persian Gulf region at a level of $+0.3 \mathrm{~m}$ as now determined in Qatar. This coincides with the famous flooding of the ancient city of Ur, originally interpreted as due to local changes in the fluvial system. We can now propose that, in fact, it was the sea level rise that triggered the fluvial reorganization and rise in ground water level that ultimately led to "the flooding of Ur".
\end{abstract}

\section{Keywords}

Sea Level Changes, Qatar, The Persian Gulf, The Flooding of Ur

\section{Introduction}

When Sir Leonard Woolley in the 1920s started to excavate the ancient city of Ur in the Chaldees and found evidence of an ancient flooding episode some 5000 years ago (Woolley, 1929), this came as a great surprise at the same time as it could be taken to confirm the old tale of a flooding in the Mesopotamian region at approximately 5000 years ago. Woolley was very clear in his interpretation, however; dismissing the concept of a general flooding episode in favour of a local event of fluvial reorganization (Woolley, 1929, 1954).

We now know that the postglacial eustatic rise in sea level from a minimum of about $-120 \mathrm{~m}$ at around 20,000 BP to its present level reached some 5000 - 6000 years ago occurred in a sequence of transgressional steps (e.g. Fairbridge, 1961; Mörner, 1971). Each of these rising sea level steps had the potential of being experienced by ancient people as a disastrous "flooding” episode.

Up to now, the flooding of the ancient city of Ur has not been able to be put into the context of sea level changes, however. Therefore, the old interpretation of a local change in the fluvial system (Woolley, 1929) has 
remained the common explanation.

Thanks to the detailed Google images of the coast of Qatar and a short field expedition in April 2006, we believe that we are now able to shed new light on the old flooding of the ancient city of Ur by a quite exact quantification of a rise in sea level and its sharp dating by radiocarbon.

\section{The Coastal Record in Qatar}

The sea level changes within the Persian Gulf are only superficially known. There is no sea level record that can be used as a regional standard; only scattered data, which often even contradict each other (the sea level reconstruction by Lambeck, 1996, is a model-based product of limited practical implication). The coast of Qatar is no exception. The issue of past sea level changes has been addressed by some authors (Vita-Finzi, 1978; Inizan, 1988) but sharp field studies and good dating still remain to be done. This paper present the initial stage of modern sea level studies in Qatar restricted to the NE-section of the coast.

The detailed Google image of the AlKhor-AlDakhira area (Figure 1) reveals a remarkable coastal record; viz. 1) a present coastal barrier system dominated by coastal stability at a present sea level position; 2 ) a gap when the coastal barrier system is absent; 3) a second coastal barrier system dominated by coastal stability at a sea level more or less the same as today; 4) a gap when the coastal barrier system is absent; and 5) a third

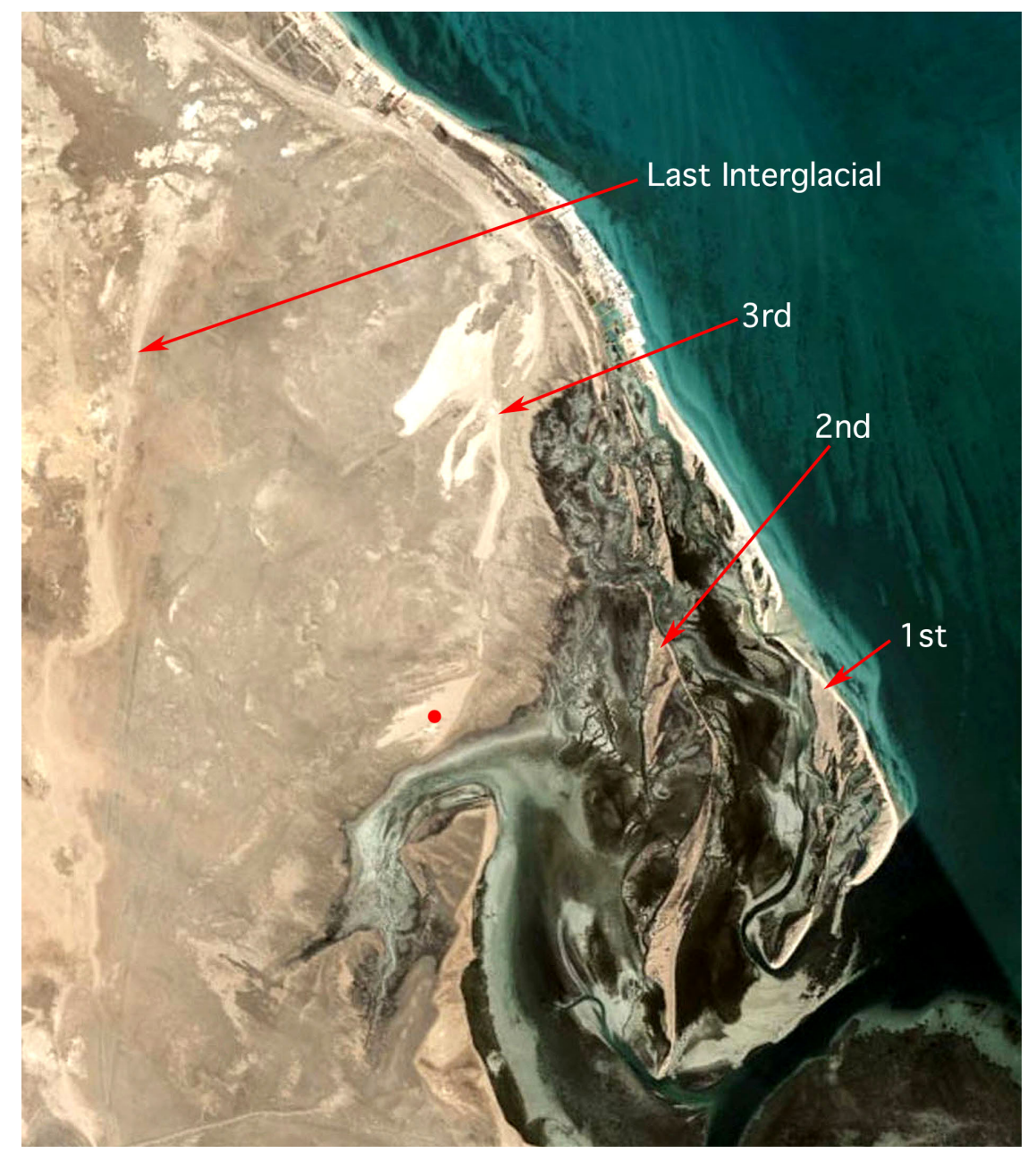

Figure 1. Google image of the Al Dahkira region in Qatar. It documents the occurrence of three stable coastal barrier systems 1) the present one; 2) an older one at the same sea level elevation; and 3) a fossil shore now on land from a period when sea level was $0.3 \mathrm{~m}$ higher than today. The $3^{\text {rd }}$ level marks the maximum Holocene sea level position and is now dated at $\sim 5000 \mathrm{cal} \cdot y r s$ BP (red dot marks sample site). The last interglacial high sea level position is seen further inlands. Each of the three coastal barrier systems represents a period of coastal stability. 
coastal barrier system clearly recognizable on the outer edges of the present land area, implying coastal stability at a sea level somewhat above the present one, and marking the peak level of the Holocene sea level transgression.

In April 2006, we undertook a short exploratory visit to the region. First we investigated a number of sites in order to determine the maximum Holocene sea level position. A fossil shore could be traced and followed over a wide area. Sometimes a coastal flat in front of the shore notch was quite wide. Its sandy sediments contained shells and corals. At all sites investigate, we found that this level surely was somewhat above the present sea level, but never more than $+0.3 \mathrm{~m}$ or at the most $+0.4 \mathrm{~m}$. This is illustrated in Figure 2 .

We then drove out over the coastal lowland to the third barrier system identified in the Google image (Figure 1). The shore character was clear. The barrier material was graded to a level some $30-40 \mathrm{~cm}$ above the present sea level. Obviously, this coastal system represents the maximum Holocene sea level. The sediments were full of marine organisms. A sample of cemented small Turitella-like shells was collected for C14-dating.

This fossil coastal barrier is covered by remains of human habitation (Figure 3); partly a habitation soil and partly stones from old buildings. Archeologically, this site is considered to belong to the Kassite period datedat about 4000 - 3500 BP. These remains represent a low sea level phase following the formation of the $3^{\text {rd }}$ coastal barrier system, formed when sea level peaked in Mid-Holocene time.

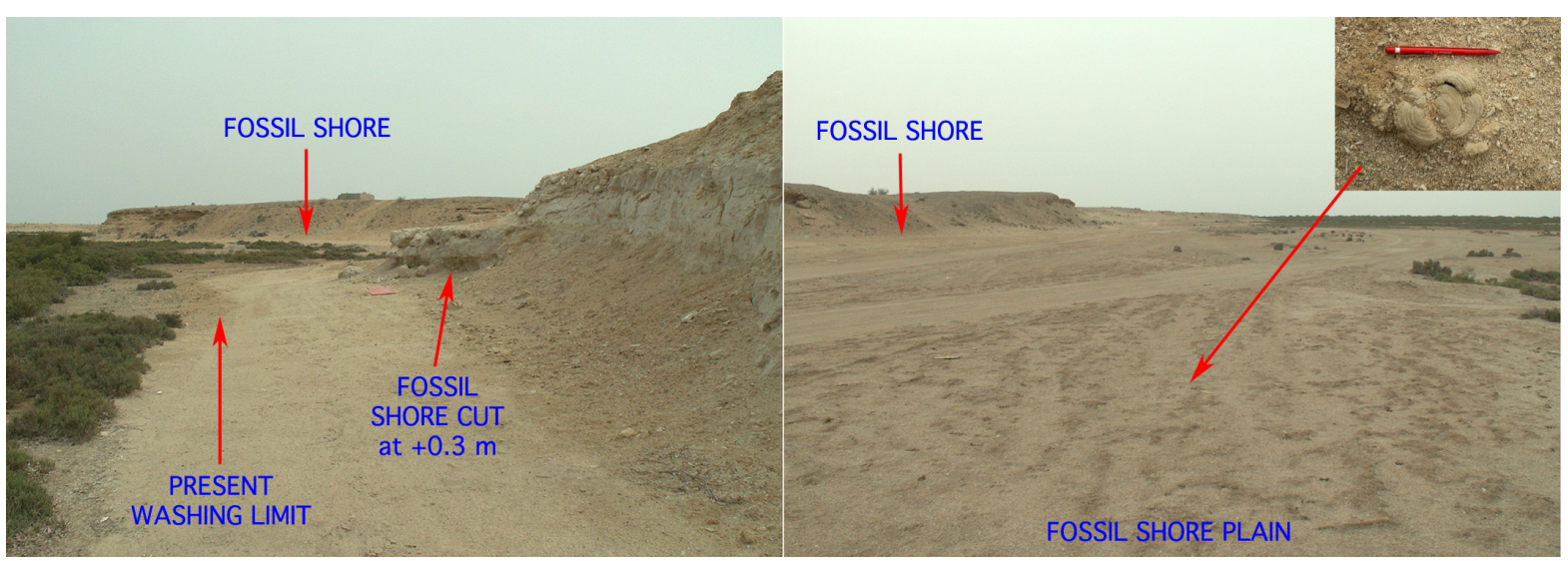

Figure 2. The fossil shore at $+0.3 \mathrm{~m}$ at AlKhor. Left: The difference in elevation between the present washing-limit and the fossil shore notch (marking the maximum Holocene sea level) is $0.3 \mathrm{~m}$ with a clear fossil shore cliff continuing over a wide area. Right: In front of the fossil cliff, there is a fairly wide coastal plain full of marine shells and even a coral (inserted picture).

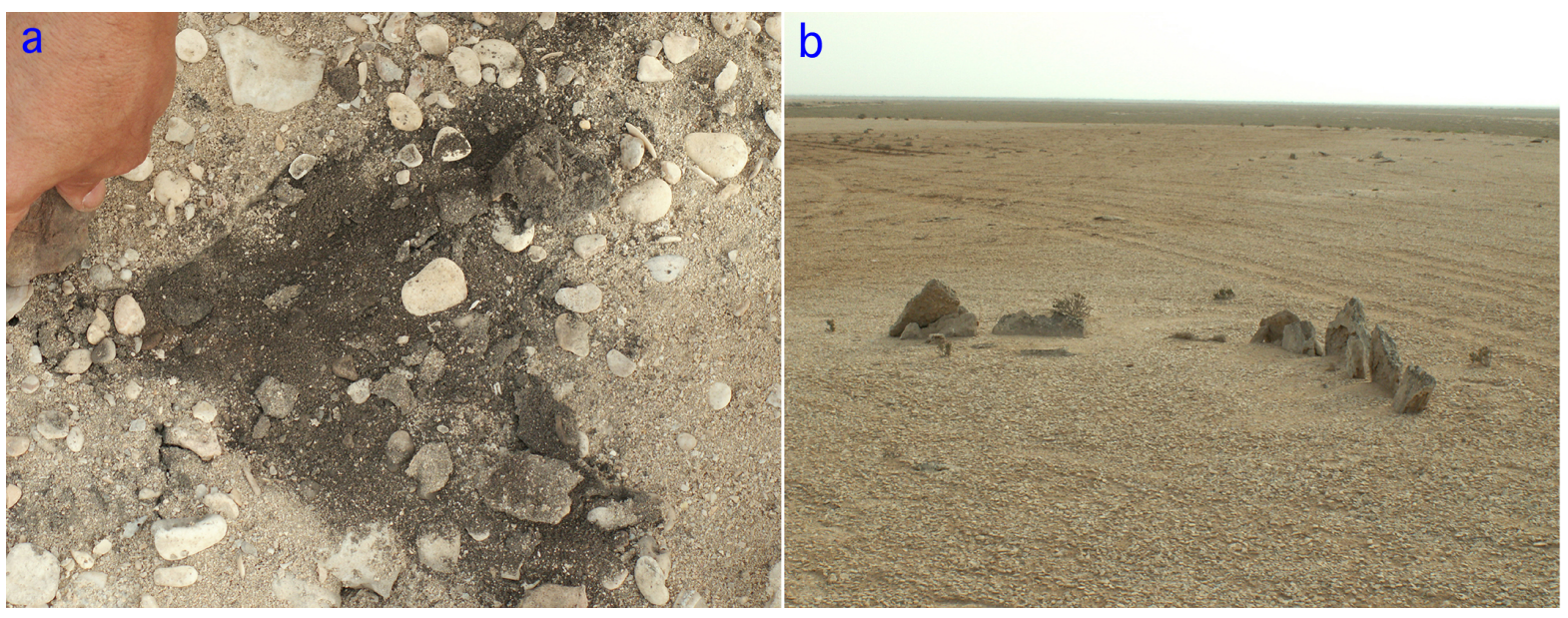

Figure 3. The soil (a) and house foundation (b) on top of the $3^{\text {rd }}$ shore barrier system and hence post-dating this sea level event. The habitation remains and the soil are believed to belong to the Kassite period dated at about 4000 - 3500 BP. Marine shells from this shore deposits beneath were C14-dated at $~ 5000 \mathrm{cal} \cdot \mathrm{yrs} \mathrm{BP}$, which gives the age of the $+0.3 \mathrm{~m}$ high sea level of the $3^{\text {rd }}$ shore stage in Figure 1. 


\section{Age of the Maximum Holocene Level}

The sample collected was C14-dated at the Uppsala Laboratory by the AMS method (Lab. no. Ua-32599). The age was $4740 \pm 40$ C14-years BP. In order to convert this age into calendar years, we need to apply two correction factors; one for the marine "reservoir effect" (minus) and one for the atmospheric fluctuations in ${ }^{14} \mathrm{C}$ content (plus).

The "reservoir effect" for the Persian Gulf is $-441 \pm 56$ years (Southon et al., 2002). This gives an age of $4299 \pm 69 \mathrm{BP}$, which after atmospheric ${ }^{14} \mathrm{C}$ correction gives a calendar age of $3150-2600 \mathrm{cal} \cdot \mathrm{yrs} \mathrm{BC}$ or $5100-$ $4550 \mathrm{cal} \cdot \mathrm{yrs} \mathrm{BP}$ at a $94.4 \%$ confidence level (and 3030 - $2870 \mathrm{cal} \cdot \mathrm{yrs} \mathrm{BC}$ or $4980-4820 \mathrm{cal} \cdot \mathrm{yrs}$ BP at a $65.6 \%$ level).

This age is exceptionally interesting and opens for wider interpretations, because it fit perfectly well with the age of the flooding of Ur. Furthermore, it represents the maximum Holocene sea level position in this region of the world; not only for Qatar but probably for the entire Persian Gulf region (Figure 4).

\section{The Flooding of Ur in New Perspectives}

The complex sedimentary evolution of the Euphrates-Tigris delta has been assessed by, for example, Lees and Falcon (1952) and Kennett and Kennett (2006), but without adequate stratigraphic, radiometric and micro-paleontological data to allow for any interpretation of age and origin of "the flooding of Ur".

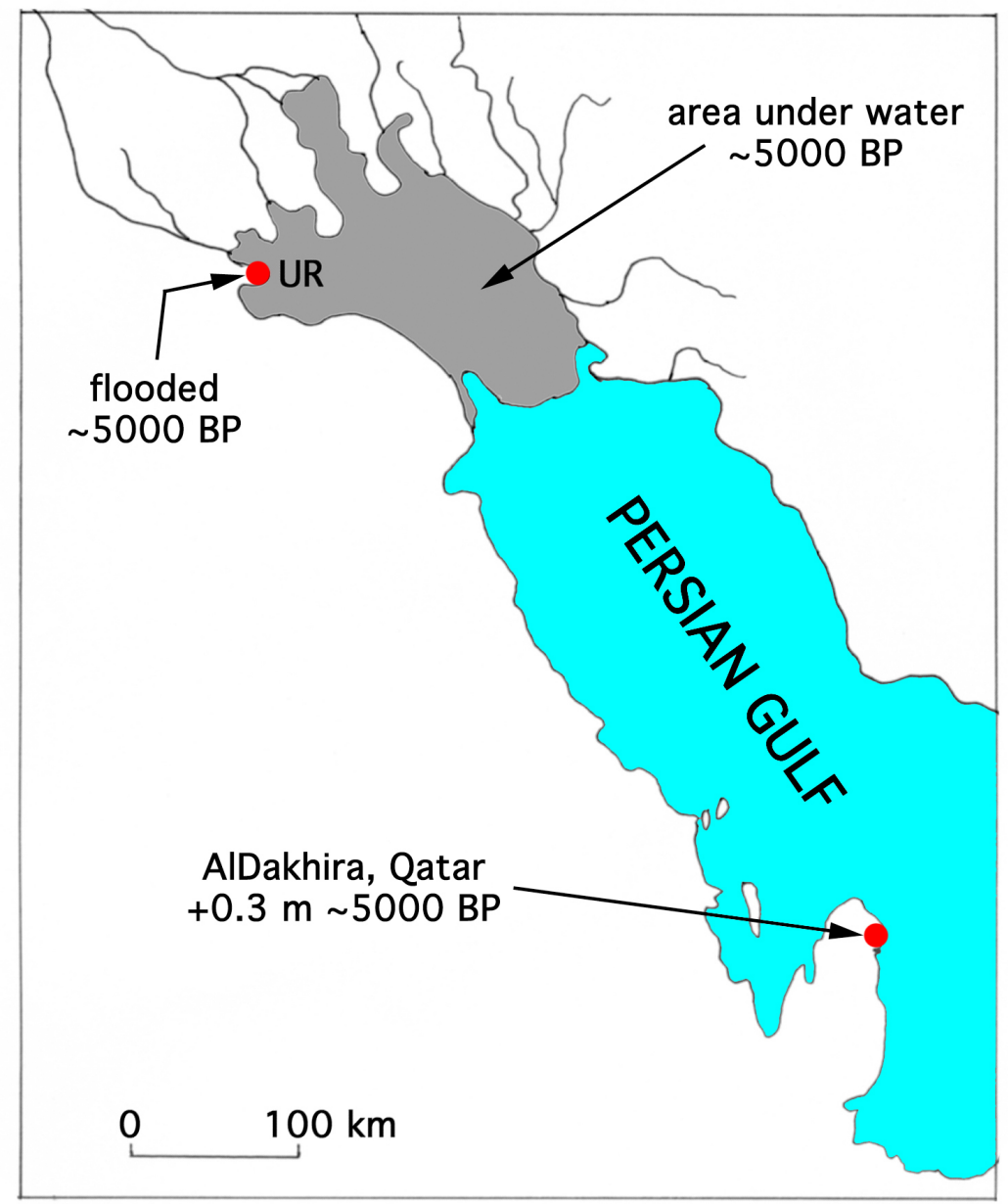

Figure 4. The Persian Gulf at $\sim 5000$ calendar years BP. 1) The ancient city of Ur was flooded; 2) The delta margin was located some $200 \mathrm{~km}$ inland; and 3) Sea level peaked at $+0.3 \mathrm{~m}$ in Qatar, a level which also represents the Holocene sea level maximum in this region. A peaking sea level rise has wide effects also upstream the fluvial delta system leading to reorganizations of the fluvial streams, erosion, re-deposition, local flooding and groundwater rise (Mörner, 1987). 
When sea level rises in a delta region, this rise has drastic direct and indirect effects far up the river system. This is especially the case in association with the peak level of the Holocene transgression, as further discussed elsewhere (e.g. Mörner, 1987). If sea level rose to a maximum level at about $5000 \mathrm{cal} \cdot \mathrm{yrs} \mathrm{BP}$, this rise co-insides with the flooding of Ur. Although, Woolley $(1929,1954)$ may be completely correct in his interpretation that this flooding was caused by a reorganization of the river systems, the ultimate driving force for this reorganization may now be given as the rise in sea level.

Consequently, a rise in sea level in to order of $0.5 \mathrm{~m}(>0.3 \mathrm{~m})$ was able to lead to a considerable reorganization of the river systems far inland. The age can now be set at about $5000 \mathrm{cal} \cdot \mathrm{yrs} \mathrm{BP}$, an age which agrees very well with the preliminary age of the flooding of Ur given by Woolley $(1929,1954)$ as well as subsequent dating of the Royal tombs above the flooding deposits (Sumeria, 2007).

The situation is illustrated in Figure 4. At around 5000 calendar years BP, the delta margin was located some $200 \mathrm{~km}$ further inlands and the ancient city of Ur, then in coastal position, was flooded and covered by a $3.7 \mathrm{~m}$ layer of clay. At precisely the same time, sea level peaked in Qatar. Therefore, we now argue that it was the sea level rise that initiated the flooding of Ur.

\section{Conclusion}

By the field studies in Qatar, we have now fixed the regional maximum Holocene sea level in elevation $(+0.3 \mathrm{~m})$ and age ( 5000 BP), and found that this event is likely to have driven the classical flooding of the ancient city of Ur.

The coastal stability of the present barrier system may be of special interest with respect to present discussions of an alarming on-going rise in sea level; pro (e.g. IPPC, 2007) and con (e.g. Mörner, 2004, 2013).

\section{Acknowledgements}

I thank Her Highness Sheikha Mozah Bint Nasser Al-Missned and the Qatar Foundation for inviting me to the Doha conference in April 2006 during which period I had the opportunity to undertake this short field investigation. Prof. Fekri Hassan, University Collage of London, and Mr. Mohamed El Obeidilee, Department of Antiquity in Doha, took part in the expedition. Prof. Göran Possnert, Uppsala University, made the C14-dating. To those persons I express my sincere thanks.

\section{References}

Fairbridge, R. W. (1961). Eustatic Changes in Sea Level. Physics and Chemistry of the Earth, 4, 99-185. http://dx.doi.org/10.1016/0079-1946(61)90004-0

Inizan, M.-L. (1988). Misionarchéologiquefrancais à Qatar. Préhistoire à Quatar, 2, 55-149.

IPPC (2007). Climate Change. Oxford: Cambridge University Press.

Kennett, D. J., \& Kennett, J. P. (2006). Early State Formation in Southern Mesopotamia; Sea-Levels, Shorelines and Climate Change. Journal of Island and Coastal Archaeology, 1, 67-99. http://dx.doi.org/10.1080/15564890600586283

Lambeck, K. (1996). Shoreline Reconstructions for the Persian Gulf since the Last Glacial Maximum. Earth Planetary Science Letters, 142, 43-57. http://dx.doi.org/10.1016/0012-821X(96)00069-6

Lees, G. M., \& Falcon, N. L. (1952). The Geographical History of the Mesopotamian Plains. The Geographical Journal, 118, 24-39. http://dx.doi.org/10.2307/1791234

Mörner, N.-A. (1971). Eustatic Changes during the Last 20,000 Years and a Method of Separating the Isostatic and Eustatic Factors in an Uplifted Area. Palaeogeography, Palaeoclimatology, Palaeoecology, 13, 1-14. http://dx.doi.org/10.1016/0031-0182(73)90046-1

Mörner, N.-A. (1987). Dynamic and Gravitational Groundwater Levels. A Two-Layer Groundwater Model. Journal of the Geological Survey of India, 29, 128-134.

Mörner, N.-A. (2013). Sea Level Changes: Past Records and Future Expectations. Energy \& Environment, 24, 509-536. http://dx.doi.org/10.1260/0958-305X.24.3-4.509

Mörner, N.-A. (2004). Estimating Future Sea Level Changes from Past Records. Global Planetary Change, 40, 49-54. http://dx.doi.org/10.1016/S0921-8181(03)00097-3

Southon, J., Kashgarian, M., Fontugne, M., Metivier, B., \& Yim, W. (2002). Marine Reservoir Correction for the Indian Ocean and Southeast Asia. Radiocarbon, 44, 167-180.

Sumeria (2007). The City of Ur. http://history-world.org/ur.htm 
Vita-Finzi, C. (1978). Environmental History. In: B. de Cardi (Ed.), Qatar Archaeological Report (pp. 11-25). Oxford: Oxford University Press.

Woolley, L. (1929). Ur of the Chaldees (31 p). London: Ernest Benn Ltd.

Woolley, L. (1954). Excavations at Ur (261 p). London: Ernest Benn Ltd. 
Scientific Research Publishing (SCIRP) is one of the largest Open Access journal publishers. It is currently publishing more than 200 open access, online, peer-reviewed journals covering a wide range of academic disciplines. SCIRP serves the worldwide academic communities and contributes to the progress and application of science with its publication.

Other selected journals from SCIRP are listed as below. Submit your manuscript to us via either submit@scirp.org or Online Submission Portal.
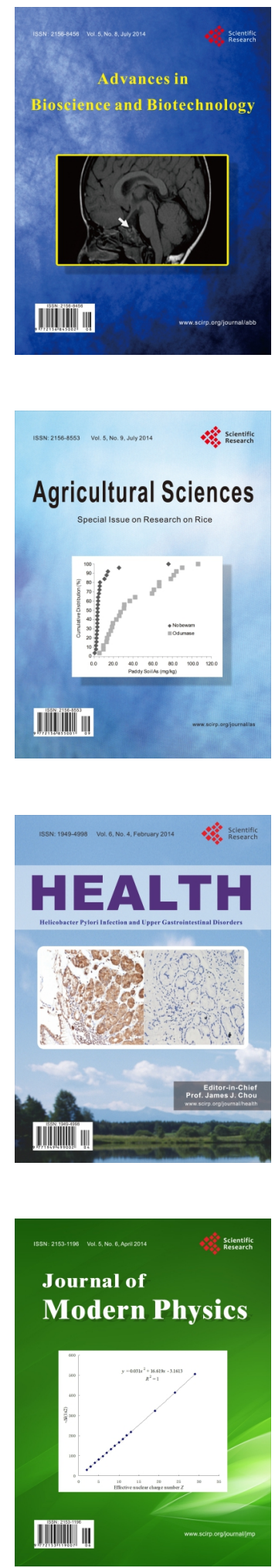
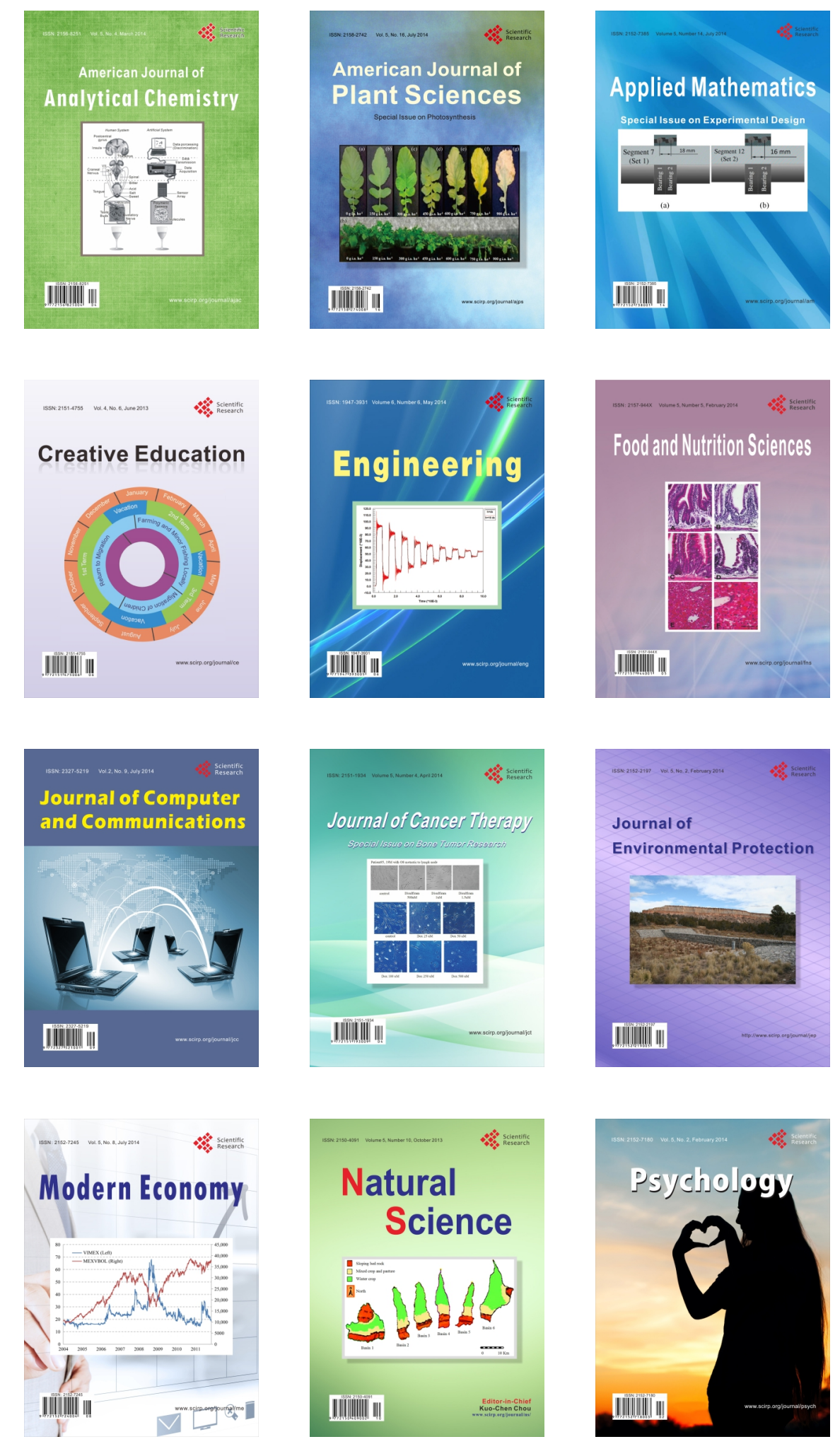